\title{
УСТОЙЧИВОСТЬ ЛИНИЙ МЯГКОЙ ПШЕНИЦЫ С ГЕНЕТИЧЕСКИМ МАТЕРИАЛОМ ВИДОВ РОДА Triticum К ГРИБНЫМ БОЛЕЗНЯМ
}

\author{
О.А. ОРЛОВСКАЯ $~$, С.И. ВАКУЛА, Л.В. ХОТЫЛЕВА
}

Потери урожая Triticum aestivum L. в результате поражения фитопатогенами в годы эпифитотий могут достигать 40-80\%. Дикие и культурные сородичи мягкой пшеницы служат перспективными источниками расширения генетического разнообразия современных сортов по локусам устойчивости. В настоящей работе на основании многолетнего мониторинга в условиях естественного инфекционного фона Беларуси впервые были показаны различия в степени поражения грибными патогенами линий пшеницы, созданных с использованием видов Triticum dicoccoides, T. dicoccum, T. durum, T. kiharae. Нашей целью было изучение устойчивости к мучнистой росе (возбудитель Blumeria graminis), септориозу (возбудитель Zymoseptoria tritici) и бурой ржавчине (возбудитель Puccinia triticina) у линий мягкой пшеницы с интрогрессией генетического материала видов рода Triticum на естественном инфекционном фоне. В исследование были включены 30 интрогрессивных линий, полученных в Институте генетики и цитологии НАН Беларуси от скрещивания сортов мягкой пшеницы Рассвет, Саратовская 29, Фестивальная, Chinese Spring, Белорусская 80, Pitic S62 с образцами тетраплоидных видов T. dicoccoides, T. dicoccum, T. durum $(\mathrm{AABB}, 2 n=28)$ и гексаплоидного искусственно синтезированного вида $T$. kiharae (A $\mathrm{A}^{\mathrm{t}} \mathrm{GGDD}$, $2 n=42$ ). Образцы чужеродных доноров получали из коллекции ВИР (г. Санкт-Петербург, Россия). Из 30 изученных линий 12 были созданы с участием образца $T$. durum, 7 - с T. dicoccoides, 6 - с T. kiharae, 5 - с T. dicoccum. Устойчивость гибридных линий пшеницы и их родительских форм к мучнистой росе, септориозу и бурой ржавчине оценивали в условиях естественного инфекционного фона на экспериментальных полях Института генетики и цитологии НАН Беларуси в 2012, 2014-2016, 2018, 2019 годах по шкале Гешеле. Степень поражения флаг-листа в фазу молочно-восковой спелости служила показателем устойчивости: 0-5 \% - высокоустойчивые растения, 5-10 \% - устойчивые, 10-15\% - среднеустойчивые, 15-25 \% - средневосприимчивые, 25-40 \% - восприимчивые, более $40 \%$ - высоковосприимчивые. Для статистической обработки данных использовали программный пакет Statistica 10.0 (критерий Краскела-Уоллиса, диаграммы размаха, двухфакторный дисперсионный анализ). В период наблюдений степень поражения восприимчивого сорта яровой мягкой пшеницы Thatcher возбудителем B. graminis составляла 40$60 \%, Z$. tritici - 15-25\%. В условиях естественного инфекционного фона Беларуси P. triticina, вызывающий листовую ржавчину пшеницы, был выявлен только в 2012 и 2014 годах (степень поражения восприимчивого контроля составила 50 \%). Дисперсионный анализ подтвердил различия средней степени поражения растений пшеницы грибными патогенами в погодных условиях шести сезонов $(\mathbf{p}<\mathbf{0 , 0 1})$. Наиболее высокую чувствительность линий пшеницы к мучнистой росе и бурой ржавчине отмечали в 2014 году, к септориозу - в 2012 году. Погодные условия этих лет способствовали интенсивному развитию болезней (высокое количество осадков, относительно низкие среднесуточные температуры воздуха, гидротермический коэффициент Селянинова выше 1,5). Наименее благоприятные условия для развития грибных патогенов были зафиксированы в засушливом 2015 году $($ ГТК $=0,8)$. Родительские сорта пшеницы были относительно устойчивы к возбудителям септориоза (< $15 \%)$ и бурой ржавчины $(<25 \%)$, но восприимчивы к мучнистой росе (до 25-40 \% поражения флаг-листа). Привлеченные в скрещивания виды рода Triticum превосходили сорта мягкой пшеницы по устойчивости к грибным болезням. Установлено, что 60,0\% интрогрессивных линий проявили высокую устойчивость к бурой ржавчине, 56,7 \% - к септориозу, 36,7 \% - к мучнистой росе. Среди линий, созданных с участием вида $T$. dicoccoides, отмечено наибольшее количество генотипов, высокорезистентных к мучнистой росе и септориозу (соответственно 71,4 и 85,7 \%), а среди линий с генетическим материалом T. dicoccum - к бурой ржавчине $(80 \%)$. Показана достоверная статистическая разница в степени поражения мучнистой росой и септориозом между группами линий, созданных с использованием образцов видов $T$. dicoccoides, T. dicoccum, T. durum, T. kiharae, и при различных погодных условиях. Устойчивость одновременно к двум заболеваниям проявило 26,7 \% интрогрессивных линий (11-1, 13-3, 15-7-2, 16-5, 34-1, 34-2, 183/2-2, 184/1-6), к трем - 23,3 \% (29, 8, 15-7-1, 1-3, 2-7, 19, 25-2). Указанные линии представляют интерес для селекции на устойчивость к грибным болезням.

Ключевые слова: виды рода Triticum, интрогрессивные линии, мучнистая роса, септориоз, бурая ржавчина.

Мучнистая роса (возбудитель Blumeria graminis (DC.) Speer f. sp. tritici March.), септориоз (возбудитель Zymoseptoria tritici (Desm.) Quaedvl. \& Crous) и бурая (листовая) ржавчина (возбудитель Puccinia triticina Erikss.) - 
наиболее распространенные болезни наземных органов мягкой пшеницы (Triticum aestivum L.). Их вредоносность проявляется главным образом в уменьшении площади листовой поверхности (и, как следствие, продуктивности фотосинтеза) и нарушении водного баланса, что вызывает преждевременное отмирание листового аппарата, снижение урожая зерновых и ухудшение его качества. Поражаются не только листья, но и листовые влагалища, стебли, а в благоприятные для развития мучнистой росы годы даже колос (1).

Заражение растений грибными патогенами возможно в широком интервале температур. Например, урединиоспоры $P$. triticina и конидии гриба B. graminis при наличии капельной влаги прорастают при 2,5-31 ${ }^{\circ} \mathrm{C}$. Конидии возбудителей септориоза распространяются в основном с каплями дождя и начинают прорастать при температуре от 5 до $35^{\circ} \mathrm{C}$ (1). Потери урожая в результате заражения этими патогенами обычно составляют 15-35 \%, но при серьезной эпифитотии могут достигать 40-80 \% (2-4).

Наиболее эффективным средством борьбы с грибными болезнями пшеницы стало создание сортов с длительной устойчивостью к патогенам. В настоящее время известны гены, контролирующие резистентность к мучнистой росе (более $90 \mathrm{Pm}$-генов), бурой ржавчине (более $75 \mathrm{Lr}$-генов) и септориозу (более $15 S t b$-генов) (5). Необходимо учитывать, что эффективность известных генов устойчивости со временем снижается, появляются новые вирулентные биотипы патогенов, способные нанести существенный урон посевам культурных злаков $(6,7)$. В связи с этим поиск новых генов устойчивости к листостебельным инфекциям - актуальная задача в селекции пшеницы.

Известно, что дикие и культурные сородичи Triticum aestivum - перспективный источник расширения генетического разнообразия современных сортов по локусам устойчивости (8-10). С целью обогащения и улучшения генофонда мягкой пшеницы в скрещивания с сортами T. aestivum нами были привлечены виды рода Triticum (T. dicoccoides, T. dicoccum, T. durum, T. kiharae). Ранее мы проанализировали характер чужеродных интрогрессий у полученных линий с помощью SSR-маркеров (11) и оценили их цитологическую стабильность в сравнении с родительскими формами (12).

В настоящей работе на основании многолетнего мониторинга в условиях естественного инфекционного фона Республики Беларусь впервые были показаны различия в степени поражения грибными патогенами линий пшеницы, созданных с использованием видов Triticum dicoccoides, T. dicoccum, T. durum, T. kiharae.

Нашей целью было изучение устойчивости к мучнистой росе, септориозу и бурой ржавчине линий мягкой пшеницы с интрогрессией генетического материала видов рода Triticum на естественном инфекционном фоне.

Методика. В исследование были включены 30 интрогрессивных линий, полученных в Институте генетики и цитологии НАН Беларуси от скрещивания сортов мягкой пшеницы Рассвет, Саратовская 29, Фестивальная, Chinese Spring (CS), Белорусская 80, Pitic S62 с образцами тетраплоидных видов $T$. dicoccoides, $T$. dicoccum, $T$. durum (AАВB, $2 n=28$ ) и гексаплоидного искусственно синтезированного вида T. kiharae (AtAtGGDD, $2 n=42)$. Образцы чужеродных доноров получали из коллекции ВИР (г. Санкт-Петербург, Россия), информация о родословных отдельных образцов не сохранилась (номера по каталогу ВИР не указаны). Из 30 изученных линий 12 были созданы с участием образца T. durum $(\mathrm{CS} \times T$. durum линии 183/2-2, 184/1-6; T. durum × CS - 190/4-1, 190/5-3, 190/6-1, 191/63, 195-3, 196-1, 202-2, 200-3; T. durum $\times$ Белоруская $80-221-1$ и 226-7), 
7 линий - с участием T. dicoccoides $($ Рассвет $\times T$. dicoccoides к-5199 - линия 29; Саратовская $29 \times T$. dicoccoides- линия 8; T. dicoccoides $\times$ Фестивальная - линии 11-1, 13-3, 15-7-1, 15-7-2, 16-5), 6 линий - с T. kiharae ( T. kiharae $\times$ Саратовская 29 - линии 19, 20-1, 25-2; T. kiharae $\times$ Фестивальная - 28, 34-1, 34-2) и 5 линий - с T. dicoccum (T. dicoccum к-45926 × Фестивальная - линии 1-3, 2-7; Pitic S62 × T. dicoccum к-45926 - 206-2, 2083, 213-1).

Устойчивость гибридных линий пшеницы, их родительских форм и восприимчивого сорта яровой мягкой пшеницы Thatcher к мучнистой роce, септориозу и бурой ржавчине оценивали в условиях естественного инфекционного фона на экспериментальных полях Института генетики и цитологии НАН Беларуси в 2012, 2014-2016, 2018, 2019 годах по шкале Гешеле. Для описания погодных условий использовали значения метеопараметров за апрель-август, предоставленные сайтом «Расписание Погоды» (http://rp5.by). Степень поражения флаг-листа в фазу молочно-восковой спелости служила показателем устойчивости: 0-5 \% - высокоустойчивые растения, 5-10\% - устойчивые, 10-15\% - среднеустойчивые, 15-25\% средневосприимчивые, 25-40 \% - восприимчивые, более $40 \%$ - высоковосприимчивые (13).

Для статистической обработки данных использовали программный пакет Statistica 10.0 («StatSoft, Inc.», США). Достоверные различия между средними значениями тестировали с помошью критерия Краскела-Уоллиса (модуль непараметрические статистики). Для оценки степени устойчивости использовали диаграммы размаха (box-and-whiskers diagram) категорированные относительно года испытания и исследуемого патогена. Различия по устойчивости к грибным патогенам между группами линий в условиях естественного инфекционного фона 6 полевых сезонов определяли с помощью двухфакторного дисперсионного анализа. Гистограммы строили в программе Microsoft Excel.

Результаты. В период наблюдений поражение восприимчивого сорта Thatcher возбудителем B. graminis составляло 40-60 \%, Z. tritici - 15$25 \%$. P. triticina, вызывающий листовую ржавчину, был выявлен только в 2012 и 2014 годах (степень поражения восприимчивого контроля 50 \%). Максимальную степень поражения сорта Thatcher мучнистой росой отмечали в 2012 году - 60 \%, в остальные годы она составляла 40 \%. Наибольшее поражение септориозом (25\%) также наблюдалось в 2012 году.

В 2012 и 2014 годах сложились наиболее благоприятные погодные условия для развития грибных болезней. Период вегетации яровой мягкой пшеницы характеризовался повышенными температурами воздуха, за исключением июня, когда показатель был ниже среднемноголетних значений. В оба года наблюдались обильные осадки в июне и августе. Самые высокие значения гидротермического коэффициента (ГТК) за 6 лет отмечали для вегетационных периодов 2012 и 2014 годов - соответственно 2,2 и 1,6. Наименее благоприятные условия для развития грибных патогенов сложились в 2015 году: был зафиксирован наиболее высокий температурный режим в июне-августе; ГТК составлял 0,8, что характеризует вегетационный период как засушливый. Особенно низкие значения ГТК отмечали в июне $(0,2)$ и августе $(0,1)$. В 2016 и 2018 годах среднемесячные температуры на протяжении всего вегетационного периода были выше среднемноголетних значений. В мае, июне и августе количество осадков оказалось немного ниже, а в июле - значительно выше среднемноголетних. ГТК составлял 1,5 в 2016 году и 1,3 в 2018 году. В 2019 году в июне наблюдалось превышение температуры воздуха и недостаток осадков по 
сравнению с нормой. В июле-августе среднемесячная температура была ниже оптимальных значений и выпали обильные осадки, ГТК составил 1,2.

Дисперсионный анализ показал значительные различия в проявлении грибных болезней у изученных генотипов пшеницы на протяжении 6 сезонов $(\mathrm{p}<0,01)$. При оценке устойчивости к бурой ржавчине анализировали только степень поражения листовой пластинки в 2012 и 2014 годах, когда патоген был обнаружен в полевых условиях. В среднем для всех генотипов наибольшую чувствительность к B. graminis и P. triticina отмечали в 2014 году, к Z. tritici - в 2012 году, когда погодные условия способствовали интенсивному развитию болезней (рис. 1).

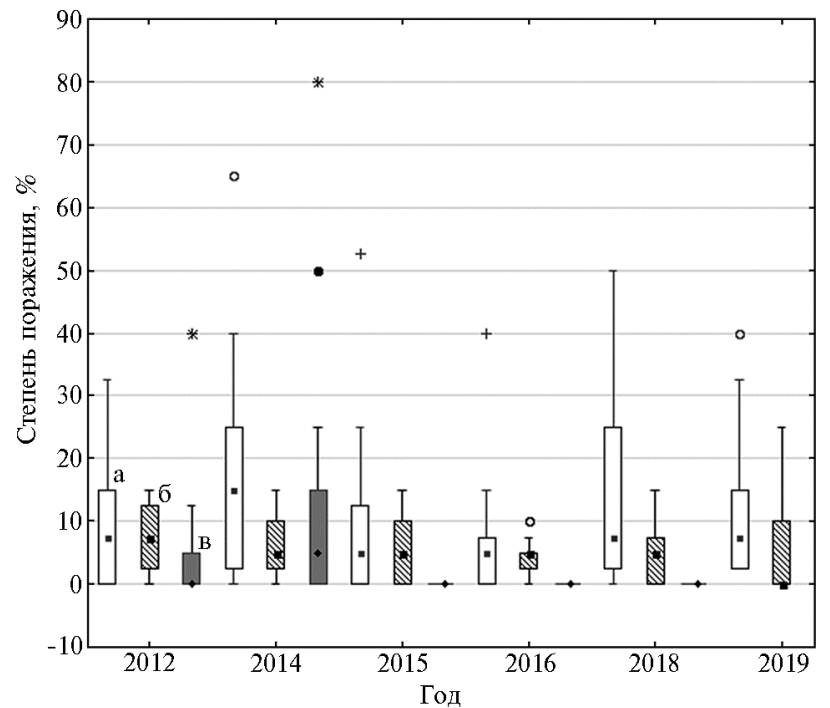

Рис 1. Степень поражения мучнистой росой (Blumeria graminis) (a), септориозом (Zymoseptoria tritici) (б) и бурой ржавчиной (Puccinia triticina) (в) у линий яровой мягкой пшеницы с интрогрессией генетического материала Triticum dicoccoides, T. dicoccum, T. durum и $T$. kiharae в течение 6 полевых сезонов: 0 , ○ - выбросы,,+ экстремумы. Мучнистая роса: $\mathrm{KW}-\mathrm{H}(5 ; 234)=17,93, \mathrm{p}=0,003$; септориоз: KW-H(5;234) = 101,94, $\mathrm{p}=0,000$; бурая ржавчина: $\mathrm{KW}$ $\mathrm{H}(5 ; 234)=26,37, \mathrm{p}=0,000$, где KW-H - критерий КраскелаУоллиса, $\mathrm{p}-$ уровень значимости (экспериментальное поле Института генетики и цитологии НАН Беларуси).

В 2014 году у части образцов степень поражения мучнистой росой превышала 60 \% (линии 206-2, 213-1, 190/5-3), бурой ржавчиной - 80 \% (линия 206-2), что было значительно выше, чем в другие годы полевых испытаний. Также было отмечено наименьшее количество генотипов с высокой устойчивостью к мучнистой росе $(27,8 \%)$ и бурой ржавчине $(44,4 \%)$. На протяжении всего периода наблюдений количество генотипов, высокорезистентных к септориозу, составляло 39,4-60,5 \%, их минимальное число выявили в 2012 году.

1. Степень поражения (\%) родительских форм интрогрессивных линий яровой мягкой пшеницы мучнистой росой, септориозом и бурой ржавчиной (экспериментальное поле Института генетики и цитологии НАН Беларуси, 2012, 2014-2016, 2018, 2019 годы)

\begin{tabular}{|c|c|c|c|}
\hline \multirow{2}{*}{ Генотип } & \multicolumn{3}{|c|}{ Степень поражения (среднее/максимальное значение) } \\
\hline & мучнистая роса & септориоз & бурая ржавчина \\
\hline \multicolumn{4}{|c|}{ Cор т a Triticum aestivum } \\
\hline Рассвет & $0 / 5$ & $5 / 10$ & 15 \\
\hline Саратовская 29 & $15 / 40$ & 10 & 15 \\
\hline Фестивальная & $15 / 25$ & 15 & $0 / 5$ \\
\hline Chinese Spring & $25 / 40$ & 15 & 15 \\
\hline Белорусская 80 & $15 / 25$ & $15 / 25$ & 15 \\
\hline Pitic S62 & 25 & 15 & 10 \\
\hline & 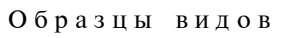 & Triticum & \\
\hline T. dicoccum $\mathrm{K}-45926$ & 0 & 0 & 0 \\
\hline T. dicoccoides & 0 & $0-5 / 5$ & 0 \\
\hline T. dicoccoides $\mathrm{K}-5199$ & 0 & $0-5$ & 0 \\
\hline T. kiharae & $5 / 10$ & 0 & 0 \\
\hline
\end{tabular}

Поражение бурой ржавчиной родительских сортов T. aestivum не превышало $15 \%$ (табл. 1). Наибольшую чувствительность к септориозу 
проявил сорт Белорусская 80, степень поражения которого достигала $25 \%$ в годы, наиболее благоприятные для развития патогена. Исходные сорта пшеницы были восприимчивы к мучнистой росе: в некоторые годы поражение флаг-листа составляло 25-40 \%. Исключением был только сорт Рассвет, который продемонстрировал высокую устойчивость к B. graminis (см. табл. 1). Виды рода Triticum характеризовались иммунностью к грибным болезням на протяжении всего периода наблюдений (см. табл. 1). Можно отметить, что синтетическая пшеница $T$. kiharae незначительно поражалась мучнистой росой.

В среднем за все годы исследований для линий с чужеродным генетическим материалом была отмечена устойчивость к септориозу: 56,7 \% генотипов показали высокоустойчивый, 33,3 \% - устойчивый, $10 \%$ среднеустойчивый тип реакции. Среди линий с генетическим материалом T. dicoccoides высокоустойчивых генотипов было больше всего (линии 29, $8,13-3,15-7-1,15-7-2,16-5)-85,7$ \% (рис. 2, А). Восприимчивых линий не выявили (см. рис. 3, А).
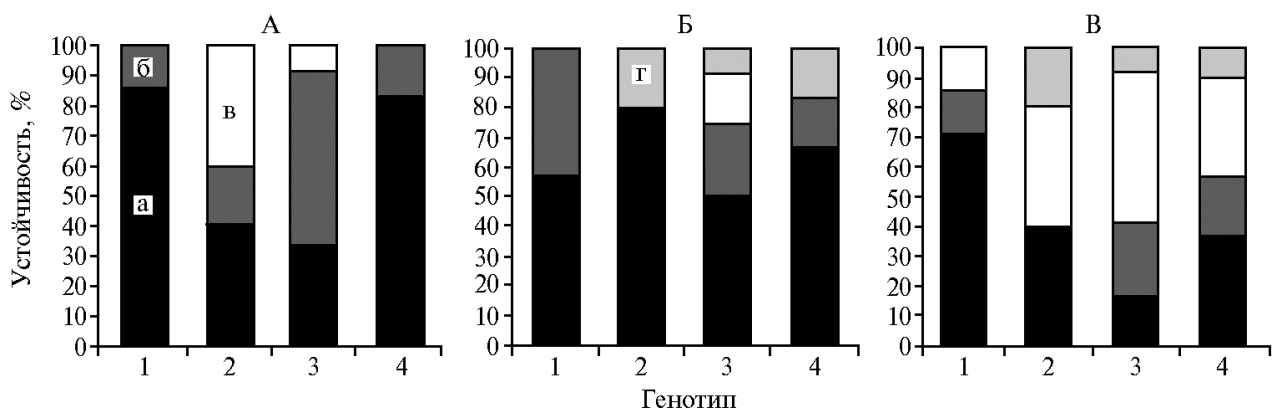

Рис. 2. Распределение линий яровой мягкой пшеницы с интрогрессией генетического материала Triticum dicoccoides (1), T. dicoccum (2), T. durum (3) и T. kiharae (4) по устойчивости к септориозу (Zymoseptoria tritici) (А), бурой ржавчине (Puccinia triticina) (Б) и мучнистой росе (Blumeria graminis) (В): а - высокоустойчивые, б - устойчивые, В - среднеустойчивые, г - восприимчивые (экспериментальное поле Института генетики и цитологии НАН Беларуси, 2012, 2014-2016, 2018, 2019 годы).

Все изученные линии превосходили родительские сорта пшеницы по резистентности к белорусской популяции септориоза, что позволяет предположить наличие генов, определяющих устойчивость к септориозу в чужеродном генетическом материале, перенесенном в геном мягкой пшеницы. Этот факт представляет большой интерес, поскольку в последние годы отмечается расширение ареала септориоза яровой пшеницы и усиление болезни, а резерв устойчивости возделываемых сортов почти исчерпан (14). В настоящее время гены устойчивости к этому патогену преимущественно картированы в геноме мягкой и твердой пшеницы (15). Дикие виды в качестве доноров генов устойчивости к септориозу недостаточно задействованы в селекции пшеницы.

Интрогрессивные линии проявили определенную степень резистентности к листовой ржавчине в 2012 и 2014 годы: 60,0 \% были высокоустойчивыми, 23,3 \% - устойчивыми, 6,7 \% - среднеустойчивыми, $10,0 \%$ - восприимчивыми. Из 30 изученных гибридных генотипов было всего 3 восприимчивых - линии 226-7 ( T. durum $\times$ Белорусская 80), 206-2 (Pitic S62 × T. dicoccum) и 20-1 (T. kiharae $\times$ Саратовская 29). У этих генотипов чувствительность к возбудителю бурой ржавчины оказалась даже выше, чем у обеих родительских форм. Возможно, гены устойчивости к листовой ржавчине, эффективные в геноме тетраплоидной пшеницы, теряют защитные свойства при интрогрессии в геном гексаплоидного вида (16). 
A

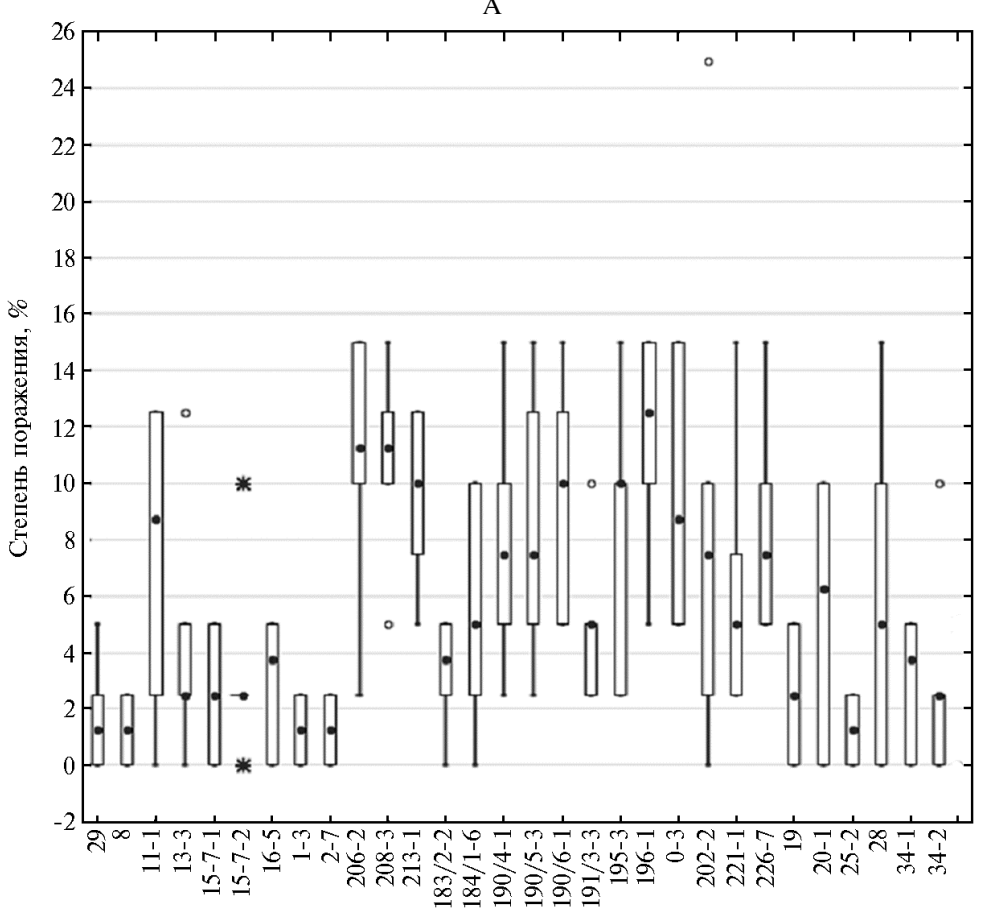

Б

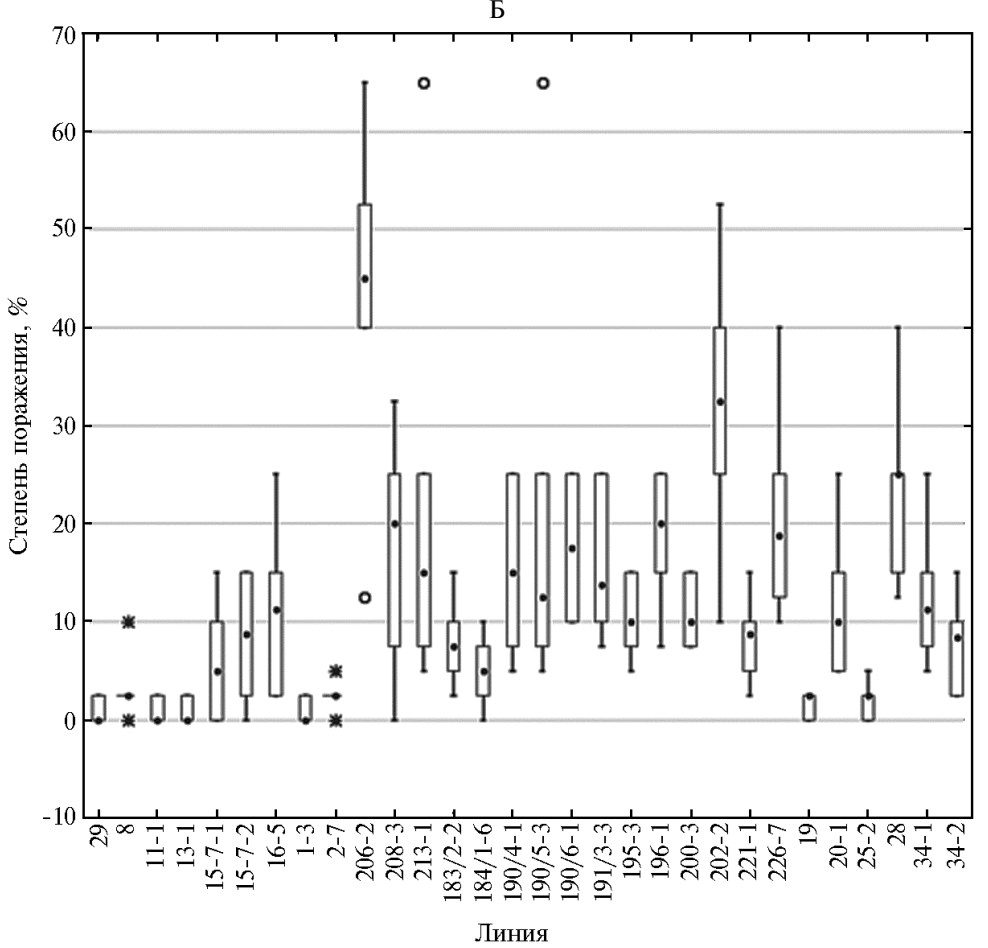

Рис. 3. Степень поражения септориозом (Zymoseptoria tritici) (А) и мучнистой росой (Blumeria graminis) (Б) у линий яровой мягкой пшеницы с интрогрессией генетического материала Triticum dicoccoides, $\boldsymbol{T}$. dicoccum, T. durum и $\boldsymbol{T}$. kiharae: • - медиана, — - 25-75\%, I - размах, О выбросы, $\boldsymbol{*}$ - экстремумы. Септориоз: $\mathrm{KW}-\mathrm{H}(29 ; 180)=86,57, \mathrm{p}=0,00$; мучнистая роса: $\mathrm{KW}-\mathrm{H}(29 ; 180)=120,75, \mathrm{p}=0,0000$, где KW-Н - критерий Краскела-Уоллиса, $\mathrm{p}-$ уровень значимости (экспериментальное поле Института генетики и цитологии НАН Беларуси, 2012, 2014-2016, 2018, 2019 годы).

Среди линий, созданных с участием T. dicoccum, было обнаружено 
наибольшее количество высокоустойчивых (80 \%). Линии T. kiharae/T. aestivum также характеризовались высоким значением по этому показателю и распределились по устойчивости к бурой ржавчине следующим образом: высокоустойчивые - 66,6 \%, устойчивые - 16,7 \%, восприимчивые $16,7 \%$ (см. рис. 2, Б). Только высокорезистентные и устойчивые линии были выделены в комбинациях скрещивания на основе T. dicoccoides (cм. рис. 2, Б). Следует отметить, что линии 29 (Рассвет $\times T$. dicoccoides $\mathrm{K}-5199)$ и 8 (Саратовская $29 \times T$. dicoccoides) продемонстрировали высокую устойчивость к P. triticina, несмотря на то что степень поражения родительских сортов пшеницы составляла $15 \%$.

Виды родов Triticum и Aegilops часто используются в качестве источников новых генов устойчивости к листовой ржавчине (17-19), поскольку большая часть идентифицированных к настоящему времени Lrгенов относится к чужеродным (5). Например, среди изученных российскими учеными интрогрессивных линий яровой пшеницы с высоким генетическим разнообразием по устойчивости к этому заболеванию присутствовали носители Lr-генов, переданных от T. durum, T. persicum, T. timopheevi, Aegilops tauschii, T. kiharae (20).

Интрогрессивные линии пшеницы оказались наиболее восприимчивыми к мучнистой росе. У трех образцов из 30 (10,0 \%) поражение листовой пластинки превышало $25 \%$. Самую высокую чувствительность имела линия 206-2 (Pitic S62 × T. dicoccum): в среднем за весь период исследования степень поражения составила более $40 \%$, а в некоторые годы достигала $65 \%$ (см. рис. 3, Б). Восприимчивость к мучнистой росе также проявили линии 202-2 (T. durum $\times$ CS) и 28 (T. kiharae $\times$ Фестивальная). Максимальная степень поражения этих генотипов была 40-50 \% и, как правило, только в 2014 году. В остальные годы наблюдений показатель составил 10-25\% (см. рис. 3, Б).

Неодинаковую устойчивость к мучнистой росе показали 27 линий: высокоустойчивые генотипы составили $36,7 \%$, устойчивые - 20,0 \%, среднеустойчивые - 33,3 \%. К устойчивым генотипам можно было отнести линии с генетическим материалом $T$. dicoccoides $-71,4 \%$ линий проявили высокоустойчивый тип реакции (см. рис. 2, В). Все линии, созданные с участием этого вида рода, превосходили родительские сорта пшеницы по резистентности к мучнистой росе. Особенно следует выделить линии 29, 11-1 и 13-3, которые, как правило, не поражались патогенном на протяжении всего периода исследования. Согласно данным литературы, дикий эммер $T$. dicoccoides - один из самых иммунных к листостебельным инфекциям вид среди сородичей мягкой пшеницы. Он служит источником ценных генов устойчивости к мучнистой росе, которые экспрессируются как на стадии проростков (Pm26, Pm42 и Pm49), так и у взрослых растений (Pm 16, Рm30, Pm31, Pm36, Pm41, Pm42, Pm49 и Pm50) (21, 22). Более $90 \%$ образцов $T$. dicoccoides мировой коллекции ВИР обладают полевой устойчивостью к мучнистой росе (23).

Различной степенью резистентности к мучнистой росе характеризовались линии T. kiharae/T. aestivum: для 36,7 \% линий был отмечен высокоустойчивый, для 20,0 \% - устойчивый, для $33,3 \%$ - среднеустойчивый тип реакции. Самая низкая степень устойчивости к мучнистой росе установлена для линий из комбинаций скрещиваний с участием $T$. durum (см. рис. 2, В): высокоустойчивые генотипы составили только 16,7 \% (линии 183/2-2 и 184/1-6). Для защиты сортов пшеницы от мучнистой росы все чаще привлекаются интрогрессированные гены устойчивости. В настоящее время известно, что в геном пшеницы переданы 26 генов устойчиво- 
сти от различных видов рода Triticum, 11 - от Aegilops ssp., 5 - от Secale cereale L., 6 - от Dasypyrum villosum (L.) Borbas, Thinopyrum ponticum (Popd.) Z.-W. Lin \& R.-C. Wang, Thinopyrum intermedium (Host) Barkworth \& D.R. Dewey и Agropryron cristatum (L.) Gaertn. (24).

Показана достоверная статистическая разница в степени поражения мучнистой росой и септориозом между группами линий, созданных с использованием видов $T$. dicoccoides, T. dicoccum, T. durum, T. kiharae, и при разных погодных условиях (табл. 2).

2. Результаты двухфакторного дисперсионного анализа устойчивости к листостебельным инфекциям у линий яровой мягкой пшеницы с интрогрессией генетического материала Triticum dicoccoides, T. dicoccum, T. durum и T. kiha$\boldsymbol{r a e}$ (экспериментальное поле Института генетики и цитологии НАН Беларуси, 2012, 2014-2016, 2018, 2019 годы)

\begin{tabular}{|c|c|c|c|c|c|}
\hline Признак & Фактор & $\mathrm{df}$ & $S S$ & $M S$ & $F$ \\
\hline Устойчивость & Генотип вида рода Triticum & 3 & 4175,65 & $1391,88^{* *}$ & 9,90 \\
\hline К мучнистой росе & Погодные условия & 5 & 2539,03 & $507,81^{* *}$ & 3,61 \\
\hline \multirow[t]{2}{*}{ (Blumeria graminis) } & Генотип вида рода Triticum × погодные условия & 15 & 1405,61 & 93,71 & 0,67 \\
\hline & Ошибка & 156 & 21937,08 & 140,62 & \\
\hline Устойчивость & Генотип вида рода Triticum & 3 & 737,33 & $245,78^{* *}$ & 12,68 \\
\hline к септориозу & Погодные условия & 5 & 278,63 & $55,73^{*}$ & 2,88 \\
\hline \multirow[t]{2}{*}{ (Zymoseptoria tritici) } & Генотип вида рода Triticum $\times$ погодные условия & 15 & 313,60 & 20,91 & 1,08 \\
\hline & Ошибка & 156 & 3022,62 & 19,38 & \\
\hline Устойчивость & Генотип вида рода Triticum & 3 & 96,32 & 32,11 & 0,36 \\
\hline к бурой ржавчине & Погодные условия & 5 & 3707,39 & $741,48 * *$ & 8,30 \\
\hline \multirow[t]{2}{*}{ (Puccinia triticina) } & Генотип вида рода Triticum × погодные условия & 15 & 457,16 & 30,48 & 0,34 \\
\hline & Ошибка & 156 & 13939,23 & 89,35 & \\
\hline
\end{tabular}

$\overline{\text { Пр и м е ч н и е. }} \mathrm{df}-$ число степеней свободы, $S S-$ сумма квадратов, $M S-$ средний квадрат, $F-$ критерий Фишера.

* и ** Статистически значимо соответственно при $\mathrm{p}<0,05$ и $\mathrm{p}<0,001$.

При создании доноров генов иммунитета к грибным болезням особую ценность представляют образцы с комплексной устойчивостью к нескольким патогенам. Близкие сородичи пшеницы часто обладают резистентностью ко многим грибным болезням. Например, в НИИ сельского хозяйства Юго-Востока (г. Саратов, Россия) было создано более 250 константных линий от скрещивания сортов пшеницы Саратовская 29, Саратовская 55 и Саратовская 58 с $T$. mопососсит, T. dicoccum, T. timopheevii, $T$. persicum, T. militinae. Из них на фоне сильной естественной эпифитотии и при искусственном заражении в условиях теплицы отобрано 178 линий с групповой устойчивостью к болезням (25). Работы по созданию новых сортов пшеницы с комплексной устойчивостью к стрессовым факторам среды посредством привлечения дикорастущих сородичей и других культурных злаков проводятся также в Краснодарском НИИ сельского хозяйства им. П.П. Лукьяненко (9) и в Сибирском НИИ сельского хозяйства (26).

В нашем исследовании устойчивость одновременно к двум заболеваниям проявило 26,7 \% интрогрессивных линий (линии 11-1, 13-3, 15-72 , 16-5, 34-1, 34-2, 183/2-2, 184/1-6), к трем - 23,3 \% (линии 29, 8, 15-7-1, 1-3, 2-7, 19, 25-2). Линии, созданные при участии $T$. dicoccoides, характеризовались групповой устойчивостью: высокая резистентность к трем патогенам была выявлена для линий 29, 8 и 15-7-1, к двум - для линий 111, 13-3, 15-7-2, 16-5. Дикая полба T. dicoccoides считается одним из предков мягкой пшеницы и служит источником генов устойчивости ко многим заболеваниям. Некоторые гены устойчивости к мучнистой росе (Pm 16 , Pm26, Pm30, Pm36, Pm41), бурой и желтой ржавчине (Lr53, Yr15, Yr35, Yr36) были картированы у $T$. dicoccoides с помощью молекулярных маркеров $(21,27)$. В настоящее время только небольшая часть этих генов интрогрессирована в геном культурной пшеницы. Также групповой устойчивостью к трем патогенам обладали две линии с генетическим материалом 
T. kiharae (19 и 25-2) и две линии с генетическим материалом $T$. dicoccum (1-3 и 2-7). Известно, что T. kiharae, выделенный в ВИР из амфидиплоида T. timopheevii $\times$ Ae. taushii, объединяет в себе комплекс признаков обоих родительских видов, в том числе устойчивость против большинства заболеваний и вредителей (28). T. dicoccum (культурная полба) возделывается человеком с самых древних времен, и в настоящее время ее популярность возрастает из-за неприхотливости к условиям выращивания и ценных питательных свойств зерна (29). Культурная полба представляет интерес и как донор генов устойчивости к биотическим и абиотическим стрессам. Так, российскими учеными в результате скрещивания с $T$. dicoccum получены 43 линии яровой мягкой пшеницы, устойчивые к бурой ржавчине и мучнистой росе; с участием видов $T$. dicoccum и $T$. persicum было получено 30 линий T. aestivum с комплексной устойчивостью (30).

Для линий с интрогрессией генетического материала T. durum отмечена высокая устойчивость только к двум патогенам: линии 183/2-2 и 184/1-6 (CS $\times$ T. durum $),$ 221-1 (T. durum $\times$ Белорусская 80). В целом линии, созданные с участием этого тетраплоидного вида, характеризовались наибольшей восприимчивостью к листостебельным инфекциям. Особенно высокую степень поражения отмечали для линий 202-2 (T. durum $\times$ CS) и 226-7 (T. durum $\times$ Белорусская 80). Однако не стоит исключать и влияние сорта, так как CS и Белорусская 80 характеризовались наибольшей восприимчивость к грибным патогенам среди родительских сортов мягкой пшеницы (см. табл. 1). Роль сорта-реципиента в проявлении устойчивости прослеживалась и среди линий, созданных с участием $T$. dicoccoides, T. dicoccum и T. kiharae. Так, для генотипов с генетическим материалом $T$. dicoccoides и T. kiharae, полученных на основе сортов Рассвет и Саратовская 29, была выявлена более высокая резистентность к мучнистой росе и септориозу, чем при использовании сорта Фестивальная.

Кроме того, что сорта пшеницы характеризуются неодинаковой устойчивостью к листостебельным инфекциям, они могут влиять на создание отдаленных гибридов: согласно данным литературы, фертильность гибридов, цитологическая стабилизация и характер рекомбинационных событий в гибридном геноме зависит от родительского сорта пшеницы $(31,32)$. Все эти процессы приводят к созданию линий с разным числом, протяженностью и локализацией фрагментов чужеродного генетического материала и, как следствие, с различными признаками. В работах ряда исследователей показано, что у устойчивых и восприимчивых к бурой ржавчине и мучнистой росе интрогрессивных линий спектр замещений и транслокаций значительно различался $(33,34)$. Очевидно, что различия по устойчивости к грибным заболеваниям, выявленные у проанализированных нами линий, также обусловлены рекомбинационными событиями с участием хромосом сородичей пшеницы, произошедшими в процессе стабилизации гибридных геномов. Результаты проведенной нами ранее оценки генетического разнообразия коллекции интрогрессивных линий пшеницы с помощью методов С-бэндинга и SSR-анализа свидетельствуют о том, что большинство линий различаются как по числу, так и по локализации чужеродных фрагментов. Установлено, что интрогрессия чужеродного генетического материала в геном T. aestivum осуществляется как в виде небольших участков, так и в виде целых хромосом (межгеномные замещения) и их фрагментов (центрические и терминальные транслокации). Наиболее высокая частота интрогрессий показана для хромосом 1А, 1B, 2A, 5B $(11,35)$. Для локализации генетических факторов, оказывающих положительное влияние на устойчивость к грибным патогенам, в дальнейшем будет проведен детальный анализ. 
Таким образом, линии яровой мягкой пшеницы, содержащие генетический материал Triticum dicoccum, T. dicoccoides, T. durum, T. kiharae, проявили высокую устойчивость к бурой ржавчине (60,0\% линий), септориозу (56,7 \% линий) и мучнистой росе $(36,7$ \% линий) на естественном инфекционном фоне в Республике Беларусь. Все изученные линии независимо от погодных условий превосходили родительские сорта по резистентности к белорусской популяции возбудителя септориоза, что позволяет предположить наличие генов, определяющих устойчивость к септориозу, в чужеродном генетическом материале гибридного генома пшеницы. Показана достоверная статистическая разница в степени поражения мучнистой росой и септориозом между группами линий, созданных с использованием видов T. dicoccoides, T. dicoccum, T. durum, T. kiharae, и при различных погодных условиях. Наибольшее число генотипов, высокоустойчивых к мучнистой росе и септориозу (соответственно 71,4 и 85,7 \%), выявлено среди линий, созданных с участием $T$. dicoccoides. Устойчивость одновременно к двум заболеваниям проявили 26,7 \% изученных интрогрессивных линий, к трем $23,3 \%$. Эти линии представляют интерес для селекции на устойчивость к грибным болезням.

Авторы благодарны к.б.н. А.А. Булойчику (Институт генетики и цитологии НАН Беларуси) за оценку полевой устойчивости линий пшеницы к грибным патогенам.

\section{ЛИТЕРАТУРА}

1. Figueroa M., Hammond-Kosack K.E., Solomon P.S. A review of wheat diseases - a field perspective. Molecular Plant Pathology, 2018, 19(6): 1523-1536 (doi: 10.1111/mpp.12618).

2. Luck J., Spackman M., Freeman A., Trebicki P., Griffiths W., Finlay K., Chakraborty S. Climate change and diseases of food crops. Plant Pathology, 2011, 60(1): 113-121 (doi: 10.1111/j.1365-3059.2010.02414.x).

3. Röll G., Batchelor W.D., Castro A.C., Simón M.R., Graeff-Hönninger S. Development and evaluation of a leaf disease damage extension in Cropsim-CERES wheat. Agronomy, 2019, 9(3): 120 (doi: 10.3390/agronomy9030120).

4. Duveiller E., Singh R.P., Nicol J.M. The challenges of maintaining wheat productivity: pests, diseases, and potential epidemics. Euphytica, 2007, 157(3): 417-430 (doi: 10.1007/s10681-007-9380-z).

5. McIntosh R.A., Dubcovsky J., Rogers J., Morris C., Xia X.C. Catalogue of gene symbols for wheat: 2017 supplement. Режим доступа: http://www.shigen.nig.ac.jp/wheat/komugi/genes/symbolClassList.jsp. Дата обращения: 20.05.2020.

6. Пахолкова Е.В., Сальникова Н.Н., Куркова Н.А. Генетическая структура региональных популяций Mycosphaerella graminicola (Septoria tritici) - возбудителя септориоза пшеницы (Triticum aestivum L.). Сельскохозяйственная биология, 2016, 51(5): 722-730 (doi: 10.15389/agrobiology.2016.5.722rus).

7. Stadlmeier M., Jørgensen L.N., Corsi B., Cockram J., Hartl L., Mohler V. Genetic dissection of resistance to the three fungal plant pathogens Blumeria graminis, Zymoseptoria tritici, and Pyrenophora tritici-repentis using a multiparental winter wheat population. G3 (Bethesda), 2019, 9(5): 1745-1757 (doi: 10.1534/g3.119.400068).

8. Disease resistance in wheat /I. Sharma (ed.). CABI, Wallingford, 2012.

9. Давоян Э.Р., Давоян Р.О., Бебякина И.В., Давоян О.Р., Зубанова Ю.С., Зинченко А.Н., Кравченко А.М. Идентификация генов устойчивости к листовой ржавчине в видах Aegilops L., синтетических формах и интрогрессивных линиях мягкой пшеницы. Вавиловский журнал генетики и селекции, 2012, 16(1): 116-122.

10. Pietrusinska A., Żurek M., Piechota U., Słowacki P., Smolinska K. Searching for diseases resistance sources in old cultivars, landraces and wild relatives of cereals. A review. Annales UMCS sectio E Agricultura, 2019, LXXIII(4): 45-60 (doi: 10.24326/asx.2018.4.5).

11. Леонова И.Н., Бадаева Е.Д., Орловская О.А., Родер М.С., Хотылева Л.В., Салина Е.А., Шумный В.К. Сравнительная характеристика гибридных линий Triticum aestivum/Triticum durum и Triticum aestivum/Triticum dicoccum по геномному составу и устойчивости к грибным болезням в различных экологических условиях. Генетика, 2013, 49(11): 1276-1283 (doi: 10.7868/S0016675813110131).

12. Орловская О.А., Соловей Л.А., Дубовец Н.И., Хотылева Л.В. Оценка цитологической стабильности линий мягкой пшеницы с интрогрессией генетического материала $T$. dicoccoides, T. dicoccum, T. kiharae. Молекулярная и прикладная генетика, 2019, 27: 52-61.

13. Гешеле Э.Э. Основы фитопатологической оценки в селекиии растений. М., 1978. 
14. Arraiano L., Brown J. Sources of resistance and susceptibility to Septoria tritici blotch of wheat: resistance and susceptibility to Septoria of wheat. Molecular Plant Pathology, 2016, 18(2): 276292 (doi: 10.1111/mpp.12482).

15. Ferjaoui S., M'Barek S.B., Bahri B., Slimane R.B., Hamza S. Identification of resistance sources to Septoria tritici blotch in old Tunisian durum wheat germplasm applied for the analysis of the Zymoseptoria tritici-durum wheat interaction. Journal of Plant Pathology, 2015, 97(3): 471481 (doi: 10.4454/JPP.V97I3.028).

16. Herrera-Foessel S.A., Singh R.P, Huerta-Espino J., William H.M, Garcia V., Djurle A., Yuen J. Identification and molecular characterization of leaf rust resistance gene Lr14a in durum wheat. Plant Disease, 2008, 92(3): 469-473 (doi: 10.1094/PDIS-92-3-0469).

17. Gill B.S., Huang L., Kuraparthy V., Raupp W.J., Wilson D.L., Friebe B. Alien genetic resources for wheat leaf rust resistance, cytogenetic transfer, and molecular analysis. Australian Journal of Agricultural Research, 2008, 59(3): 197-208 (doi: 10.1071/AR07315).

18. Narang D., Kaur S., Steuernagel B. Ghosh S., Bansal U., Li J., Zhang P., Bhardwaj S., Uauy C., Wulff B.B.H., Chhuneja P. Discovery and characterisation of a new leaf rust resistance gene introgressed in wheat from wild wheat Aegilops peregrina. Sci. Rep., 2020, 10(1): 7573 (doi: 10.1038/s41598-020-64166-2).

19. Aktar-Uz-Zaman M., Tuhina-Khatun M., Hanafi M.M., Sahebi M. Genetic analysis of rust resistance genes in global wheat cultivars: an overview. Biotechnology \& Biotechnological Equipment, 2017, 31(3): 431-445 (doi: 10.1080/13102818.2017.1304180).

20. Гультяева Е.И., Сибикеев С.Н., Дружин А.Е., Шайдаюк Е.Л. Расширение генетического разнообразия сортов яровой мягкой пшеницы по устойчивости к бурой ржавчине (Puccinia triticina Eriks.) в Нижнем Поволжье. Сельскохозяйственная биология, 2020, 55(1): 27-44 (doi: 10.15389/agrobiology.2020.1.27rus).

21. Peng J.H., Sun D.F., Peng Y.L., Nevo E. Gene discovery in Triticum dicoccoides, the direct progenitor of cultivated wheats. Cereal Research Communications, 2013, 41(1): 1-22 (doi: 10.1556/CRC.2012.0030).

22. Hua W., Liu Z., Zhu J., Xie C., Yang T., Zhou Y., Duan X., Sun Q., Liu Z. Identification and genetic mapping of $p m 42$, a new recessive wheat powdery mildew resistance gene derived from wild emmer (Triticum turgidum var. dicoccoides). Theor. Appl. Genet., 2009, 119: 223-230 (doi: 10.1007/s00122-009-1031-4).

23. Ахмедов М.А. Устойчивость Triticum dicoccum (Schranc.) Schuebl. к популяции мучнистой росы и особенности ее наследования. Генетика, 1998, 34(10): 1376-1382.

24. Kang Y., Zhou M., Merry A.M., Barry K.M. Mechanisms of powdery mildew resistance of wheat a review of molecular breeding. Plant Pathology, 2020, 69(4): 611-617 (doi: 10.1111/ppa.13166).

25. Маркелова Т.С., Иванова О.В., Баукенова Э.А., Нарышкина Е.А., Салмова М.Ф. Создание доноров групповой устойчивости яровой мягкой пшеницы к грибным болезням с использованием трансгрессии генов устойчивости от диких видов и сородичей пшеницы. Аграрный вестник Юго-Востока, 2014, 1-2: 25-27.

26. Белан И.А. Использование интрогрессивной гибридизации в селекции яровой мягкой пшеницы. Российская сельскохозяйственная наука, 2016, 1: 5-8.

27. Ben-David R., Xie W., Peleg Z., Saranga Y., Dinoor A., Fahima T. Identification and mapping of PmG16, a powdery mildew resistance gene derived from wild emmer wheat. Theor. Appl. Genet., 2010, 121(3): 499-510 (doi: 10.1007/s00122-010-1326-5).

28. Liu X., Zhang M., Liu X., Li H., Hao M., Ning Sh., Yuan Zh., Liu D., Wu B., Chen X., Chen W., Zhang L. Molecular cytogenetic identification of newly synthetic Triticum kiharae with high resistance to stripe rust. Genetic Resources and Crop Evolution, 2018, 65: 1725-1732 (doi: 10.1007/s10722-018-0649-y).

29. Смекалова Т.Н., Кобылянский В.Д. Новый подвид пшеницы Triticum dicoccon (Shrank) Schuebl. subsb. nidicoccon Kobyl. et Smekal. Труды по прикладной ботанике, генетике и селекции, 2019, 180(4): 148-151.

30. Маркелова Т.С., Веденеева М.Л., Кириллова Т.В. Результаты селекции пшеницы на комплексную устойчивость к болезням. Вестник защиты растений, 2003, 3: 25-30.

31. Bashir T., Mishra R.C., Hasan M.M., Mohanta T.K., Bae H. Effect of hybridization on somatic mutations and genomic rearrangements in plants. International Journal of Molecular Science, 2018, 19(12): 3758 (doi: 10.3390/ijms19123758).

32. Whitford R., Fleury D., Reif J.C., Garcia M., Okada T., Korzun V., Langridge P. Hybrid breeding in wheat: technologies to improve hybrid wheat seed production. Journal of Experimental Botany, 2013, 64(18): 5411-5428 (doi: 10.1093/jxb/ert333).

33. Badaeva E.D., Budashkina E.B., Bilinskaya E.N., Pukhalskiy V.A. Intergenomic chromosome substitutions in wheat interspecific hybrids and their use in the development of a genetic nomenclature of Triticum timopheevii chromosomes. Russian Journal of Genetics, 2010, 46(7): 769-785.

34. Petrash N., Leonova I., Adonina I., Salina E. Effect of translocations from Aegilops speltoides Tausch on resistance to fungal diseases and productivity in common wheat. Russian Journal of Genetics, 2016, 52(12): 1253-1262 (doi: 10.1134/S1022795416120097).

35. Orlovskaya O.A., Dubovets N.I., Solovey L.A., Bondarevich E.B., Leonova I.N. Molecular cytogenetic analysis of alien introgressions in common wheat lines with T. kiharae genetic materi- 
al. Proc. of the Fifth International scientific conference «Current challenges in plant genetics, genomics, bioinformatics, and biotechnology» /A. Kochetov, E. Salina (eds.). Novosibirsk, 2019: 235-237.

ГНУ Институт генетики и цитологии НАН Беларуси,

220072 Республика Беларусь, г. Минск, ул. Академическая, 27,

e-mail: O.Orlovskata@igc.by $₫$, svettera@yandex.ru, L.Khotyleva@igc.by
Поступила в редакцию

9 октября 2020 года

Sel'skokhozyaistvennayabiologiya [Agricultural Biology], 2021, V. 56, № 1, pp. 171-182

\title{
STUDY OF BREAD WHEAT LINES WITH GENETIC MATERIAL OF Triticum SPECIES FOR RESISTANCE TO FUNGAL DISEASES
}

\author{
O.A. Orlovskaya ${ }^{\bowtie}$, S.I. Vakula, L.V. Khotyleva
}

Institute of Genetic and Cytology of National Academy of Science of Belarus, 27, ul. Akademicheskaya, Minsk, 220072 Republic of Belarus, e-mail O.Orlovskata@igc.by ( $\square$ corresponding author), svettera@yandex.ru, L.Khotyleva@igc.by ORCID:

Orlovskaya O.A. orcid.org/0000-0002-1187-1317 Khotyleva L.V. orcid.org/0000-0003-0295-5022

Vakula S.I. orcid.org/0000-0002-2242-7107

The authors declare no conflict of interests Acknowledgements:

The authors thank A.A. Buloichik (Institute of Genetics and Cytology of the National Academy of Sciences of Belarus) for evaluation of resistance to the fungal pathogens of wheat lines in the field conditions.

Received October 9, 2020 doi: 10.15389/agrobiology.2021.1.17leng

\section{Abstract}

Triticum aestivum L. yield losses caused by phytopathogens can reach 40-80\% in epiphytotic years. Wild and cultivated relatives of common wheat are promising sources of broadening the genetic diversity of resistance loci for modern varieties. For the first time differences in the degree of infection by fungal pathogens of wheat lines obtained from crossing with Triticum dicoccoides, T. dicoccum, T. durum, T. kiharae were shown on the basis of long-term monitoring under conditions of the natural infectious background of Belarus. In our work, we studied the resistance of bread wheat lines with Triticum species introgressions to powdery mildew (Blumeria graminis), septoria (Zymoseptoria tritici), and leaf rust (Puccinia triticina) in a natural infectious background. We studied 30 introgression lines obtained in the Institute of genetics and cytology NAS of Belarus from crossing of six varieties of common wheat (Rassvet, Saratovskaya 29, Festivalnaya, Chinese Spring, Belorusskaya 80, Pitic S62) with accessions of tetraploid species T. dicoccoides, $T$. dicoccum, T. durum (AABB, $2 n=28$ ) and with hexaploid synthetic variety $T$. kiharae (A $\mathrm{A}^{\mathrm{t} G G D D,} 2 n=42$ ). Twelve of the studied wheat lines were obtained with $T$. durum contribution, 7 - with $T$. dicoccoides, $6-$ with $T$. kiharae, 5 - with $T$. dicoccum. The evaluation of resistance to the diseases was performed in a naturally occurring infectious background on the experimental fields of the Institute of Genetics and Cytology of the NAS of Belarus during 2012, 2014-2016, 2018, 2019 field seasons using Geshele's scale. We used the extent of flag leaf damage in the milky-wax ripeness phase as an indicator of resistance: 0-5 \% - highly resistant plants, 5-10\% - resistant, 10-15\% - medium resistant, 15-25\%medium susceptible, 25-40\% - susceptible. Statistica 10.0 software package was used for statistics (Kruskal-Wallis test, box-and-whiskers diagram, two-way ANOVA). The extent of flag leaf damage for the susceptible spring bread wheat variety Thatcher accounted 40-60\% by B. graminis and $15-25 \%$ by $Z$. tritici during studied period. P. triticina, which causes wheat leaf rust, was detected only in 2012 and 2014 in a naturally occurring infectious background of Belarus (the degree of damage of susceptible control was $50 \%$ ). ANOVA confirmed the differences in the average degree of damage to wheat plants by fungal pathogens under weather conditions of six field seasons $(p<0,01)$. The highest sensitivity of wheat lines to powdery mildew and leaf rust was noted in 2014, to septoria blight - in 2012. The weather conditions of these years contributed to the intensive development of diseases (high precipitation, relatively low average daily air temperatures, Selyaninov's hydrothermal coefficient above 1.5). The least favorable conditions for the development of fungal pathogens were recorded in dry 2015 year (hydrothermal coefficient $=0.7$ ). The species of genus Triticum were superior to common wheat varieties in resistance to fungal diseases. It was found that $60.0 \%$ of introgression lines showed a high level of resistance to leaf rust, $56.7 \%$ to septoria, and $36.7 \%$ to powdery mildew. The highest number of highly resistant to powdery mildew and septoria genotypes were noted among the lines created on the base of $T$. dicoccoides $(71.4 \%$ and $85.7 \%$, respectively). Resistance to leaf rust $(80 \%)$ was common among lines with $T$. dicoccum genetic material. A significant statistical difference in the degree of damage by powdery mildew and septoria was shown between the groups of lines created using the species $T$. dicoccoides, T. dicoccum, T. durum, T. kiharae, and under different weather conditions. A total of $26.7 \%$ of introgression lines demonstrated resistant to two diseases (lines 11-1, 13-3, 15-7-2, 16-5, 34-1, 34-2, 183/2-2, 184/1-6), $23.3 \%$ - to three infections (lines $29,8,15-7-1,1-3,2-7,19,25-2)$. These lines are of interest in breeding for fungal disease resistance.

Keywords: genus Triticum, introgression lines, powdery mildew, septoria, leaf rust. 